\title{
Pengenalan Perencanaan Program Desa Berbasis Bukti: Studi Di Desa Murtajih Kecamatan Pademawu Kabupaten Pamekasan
}

\author{
Agus Aan Adriansyah, Nurul Jannatul Firdausi, Tri Deviasari Wulan
}

Prodi S1 Ilmu Kesehatan Masyarakat Fakultas Kesehatan, Universitas Nahdlatul Ulama Surabaya

\author{
Email: aan.naufal87@unusa.ac.id \\ DOI: https://doi.org/10.21107/pangabdhi.v5i2.6071.g3777
}

\begin{abstract}
Abstrak
Pembangunan desa memerlukan dukungan dari dana desa. Dana desa yang dikelola haruslah diimbangi dengan penyusunan perencanaan yang baik dan mempertimbangkan prioritas masalah yang ada di desa, sehingga efektivitas program yang dijalankan dapat sesuai dengan tujuan dan harapan pemerintah dalam mendukung pembangunan nasional. Desa Murtajih merupakan desa di Kecamatan Pademawu, Pamekasan yang masih menghadapi kesulitan dalam pelaksanaan manajemen perencanaan desa. Disebabkan karena keterbatasan perangkat desa dalam mengoperasikan komputer, perangkat desa belum mendapatkan pelatihan tentang perencanaan, dan penyusunan dokumen planning of action (POA) dalam perencanaan desa. Pengabdian masyarakat ini menyasar perangkat desa, kader, pengurus pokja PKK dan bidan desa. Penelitian dilakukan dengan menganalisis pengetahuan perangkat desa dan pihak lainnya tentang penyusunan perencanaan, intervensi dengan pemberian materi pengenalan perencanaan program desa berbasi bukti dan memperkaya wawasan dalam menggunakan data untuk menyusun perencanaan. Target kegiatan penelitian ini adalah peningkatan pengetahuan peserta tentang perencanaan program berbasis bukti. Pengukuran pengetahuan meliputi peran perencanaan terhadap anggaran, proses dan sumber data untuk perencanaan program serta pelaksanaan perencanaan dan evaluasi. Hasil pengukuran pengetahuan peserta pengabdian kepada masyarakat melalui pre-test dan post-test menunjukkan informasi, hasil pre-test terbanyak adalah dalam kategori pengetahuan cukup baik $(61,11 \%)$ dan post-test dalam kategori pengetahuan baik $(94,44 \%)$. Terjadi peningkatan pengetahuan pada 15 responden $(83,33 \%)$, hal ini menunjukkan bahwa mayoritas responden mengalami peningkatan pengetahuan mengenai dana desa setelah pelaksanaan kegiatan sosialisasi. Pengetahuan responden terkait proses dan sumber data perencanaan program meningkat hingga 92,2\% dengan efektivitas sosialisasi yang menunjukkan nilai signifikansi sebesar $0,001(<$ nilai $\alpha$ ), yang menunjukkan adanya efektivitas sosialisasi dalam meningkatkan pengetahuan.
\end{abstract}

Kata kunci: dana desa, kesehatan, masyarakat desa, pembangunan desa

\section{PENDAHULUAN}

Desa memiliki sebuah kewenangan dalam mengatur perkembangan dan pembangunan masyarakat desa sejak dikeluarkannya Undangundang Nomor 6 Tahun 2014 tentang Desa. Undang-undang tersebut, menjadi dasar dalam menjelaskan kedudukan dan relasi sebuh desa dengan daerah dan pemerintah yang meliputi aspek kewenangan, perencanaan, pembangunan, keuangan dan demokrasi desa (Letty, 2016). Dana tentu sangat diperlukan dalam melakukan pembangunan desa. Sejauh ini, sumber dana operasional desa dapat berasal dari Pendapatan Asli Daerah, Alokasi Dana Desa, Bagian dari DPRD Kab/Kota, Bantuan keuangan dari APBD, alokasi APBN, hibah/sumbangan dari pihak ketiga dan sumber dana sah lainnya (Kementerian Keuangan RI, 2017). Besarnya dana yang dikelola, harus diimbangi dengan perencanaan yang baik dan mempertimbangkan prioritas masalah yang muncul di desa. Pembangunan daerah diukur melalui Indeks Pembangunan Masyarakat (IPM). Selama 3 tahun terakhir, angka IPM Kabupaten Pamekasan (Tahun 2013: 62,27; Tahun 2014: 62,66; Tahun 2015:63,10) tertinggi dibandingkan dengan 4 kabupaten lainnya di Pulau Madura, namun masih rendah jika dibandingkan dengan kabupaten/kota yang ada di daerah Jawa Timur https://jatim.bps.go.id/ linkTabelStatis/view/id/235). Desa Murtajih terdiri dari 8 dusun, diantaranya Dusun Murtajih, Nanggirik, Oberan, Telaga Sari, Soloh Timur, 
Soloh Dajah, Soloh Laok dan Pao Gading. Luas desa Murtajih adalah 323,183 Ha dengan bentang wilayah seluruhnya berupa daratan dengan ketinggian daratan dari permukaan laut yaitu 15 meter. Durasi musim penghujan rata-rata 5 bulan dengan curah hujan $36 \mathrm{~mm}$ dan suhu udara sekitar 28-32 ${ }^{\circ} \mathrm{C}$. Jumlah total penduduk sebanyak 5.945 jiwa dengan 1.822KK (Kepala Keluarga). Jumlah penduduk perempuan 3.055 dan 2.890 laki-laki. Sebagian besar penduduk di Desa Murtajih bermata pencaharian petani (484 orang), namun masih banyak juga penduduk yang belum bekerja yaitu sebanyak 649 orang (12\%).

Desa Murtajih masih menghadapi kesulitan dalam dalam perencanaan desa. Hal-hal yang berkontribusi pada masalah tersebut diantaranya: 1. Sumber Daya Manusia. Jumlah perangkat desa sebanyak 14 orang dan hanya 7 orang yang mampu mengoperasikan komputer. Keterbatasan perangkat desa dalam mengoperasikan komputer, salah satunya berdampak pada pengolahan data desa yang kurang informatif bahkan masih banyak laporan kegiatan desa yang belum terolah dengan baik. Akhirnya akan berimbas kepada perencanaan program desa, terutama dalam merencanakan kegiatan berbasis bukti dan prioritas kegiatan sesuai Peraturan Menteri Desa, Pembangunan Daerah Tertinggal dan Transmigrasi RI No 22 tahun 2016 tentang Penetapan Prioritas Penggunaan Dana Desa Tahun 2017. Selain itu, perangkat desa belum pernah mendapatkan pengalaman pelatihan tentang perencanaan program. 2. Berdasarkan hasil penelitian yang dilakukan Firdausi, et al (2017) bahwasannya perencanaan desa sudah melibatkan masyarakat di dalam kegiatan musyawarah dusun (musdus) namun dalam pembuatan perencanaan desa hanya menyesuaikan kebutuhan masyarakat dalam musyawarah tanpa menggunakan data sebagai pendukung, pembuatan dokumen planning of action (POA) belum dilakukan sehingga tanggung jawab kegiatan tidak merata dan kegiatan cukup sulit untuk dievaluasi karena indikator keberhasilan belum dituliskan dalam pelaporan. Kegiatan pengabdian kepada masyarakat ini diharapkan membantu meningkatkan pengetahuan dan keterampilan perangkat desa penyusunan perencanaan serta dapat menghasilkan dokumen perencanaan program bidang kesehatan yang sesuai dengan permasalahan yang ada.

\section{METODE}

Penelitian ini dilakukan di Desa Murtajih Kecamatan Pademawu Pamekasan pada bulan Juni s/d Juli tahun 2019. Jenis penelitian ini adalah penelitian kuantitatif. Variabel yang diteliti adalah pengetahuan dan pemahaman perangkat desa dan pihak lainnya yang terkait dalam penyusunan perencanaan program desa. Populasi dalam penelitian ini adalah perangkat desa dan pihak yang terkait dengan total sampel sejumlah 18 responden. Data primer dalam penelitian ini diperoleh dari instrumen penelitian menggunakan kuesioner. Sedangkan data sekunder dengan melakukan kajian dokumen realisasi dana desa tahun 2016-2018. Data dianalisis menggunakan analisis deskriptif dan bivariate dengan uji Wilcoxon.

\section{HASIL DAN PEMBAHASAN Pengetahuan Peserta}

Pengetahuan merupakan hasil tahu dan hal ini terjadi setelah seseorang melakukan penginderaan terhadap suatu obyek tertentu. Pada kegiatan pengabdian kepada masyarakat ini, para peserta diberikan penyuluhan berupa sosialisasi pemanfaatan dana desa. Evaluasi pengukuran penilaian tingkat pengetahuan dari para peserta dilakukan dengan metode pretest dan posttest. Berikut hasil selengkapnya.

Tabel 1. Tingkat Pengetahuan Peserta Berdasarkan Penilaian Pretest

\begin{tabular}{|c|l|c|c|}
\hline No. & \multicolumn{1}{|c|}{$\begin{array}{c}\text { Penilaian } \\
\text { Pretest }\end{array}$} & Frekuensi & Persentase \\
\hline 1. & $\begin{array}{l}\text { Pengetahuan } \\
\text { Baik }\end{array}$ & 7 & 38,89 \\
\hline 2. & $\begin{array}{l}\text { Pengetahuan } \\
\text { Cukup }\end{array}$ & 11 & 61,11 \\
\hline 3. & $\begin{array}{l}\text { Pengetahuan } \\
\text { Kurang }\end{array}$ & 0 & 0,00 \\
\hline \multicolumn{2}{|l|}{ Total } & 18 & 100,00 \\
\hline
\end{tabular}

Berdasarkan Tabel 1 membuktikan bahwa sebagian besar peserta telah memiliki tingkat pengetahuan yang cukup mengenai pemanfaatan dana desa $(61,11 \%)$. Sedangkan sisanya adalah peserta yang tingkat pengetahuan baik $(38,89 \%)$. Hasil ini menunjukkan bahwa pengetahuan awal para peserta mengenai pemanfaatan dana desa sudah cukup baik.

Setelah pemberian pretest, peserta selanjutnya diberikan sosialisasi mengenai pemanfaatan dana desa secara mendalam. Pemberian sosialisasi tersebut diharapkan dapat menambah wawasan 
dan pengetahuan para peserta mengenai dana desa dan bagaimana pemanfaatannya yang benar. Berikut hasil evaluasi pengukuran pengetahuan para peserta mengenai pemanfaatan dana desa setelah pemberian sosialisasi.

Tabel 2. Tingkat Pengetahuan Peserta Berdasarkan Penilaian Posttest

\begin{tabular}{|r|c|c|c|}
\hline No. & Penilaian Prottest & $\begin{array}{c}\text { Freku } \\
\text { ensi }\end{array}$ & Persentase \\
\hline 1 & Pengetahuan Baik & 17 & 94,44 \\
\hline 2 & Pengetahuan Cukup & 1 & 5,56 \\
\hline 3 & Pengetahuan Kurang & 0 & 0,00 \\
\hline \multicolumn{2}{r|}{ Total } & 18 & 100,00 \\
\hline
\end{tabular}

Berdasarkan Tabel 2 dapat diinformasikan bahwa mayoritas para peserta telah memiliki tingkat pengetahuan yang baik mengenai pemanfaatan dana desa $(94,44 \%)$. Sedangkan sisanya adalah peserta yang tingkat pengetahuan cukup baik $(5,56 \%)$. Hasil pemberian posttest secara umum menandakan bahwa pengetahuan para peserta mengenai pemanfaatan dana desa seusai sosialisasi telah terjadi peningkatan pengetahuan yang lebih baik dibandingkan dengan saat evaluasi pretest.

Evaluasi hasil penilaian dari perbandingan penilaian pada pretest dan posttest, dapat dilihat pada Tabel 3 berikut ini.

Tabel 3. Evaluasi Perubahan Penilaian Tingkat Pengetahuan Pasca Pemberian Sosialisasi

\begin{tabular}{|c|c|c|c|}
\hline No. & $\begin{array}{c}\text { Perubahan } \\
\text { Penilaian }\end{array}$ & Frekuensi & Persentase \\
\hline 1. & $\begin{array}{c}\text { Pengetahuan } \\
\text { Tetap }\end{array}$ & 3 & 16,70 \\
\hline 2. & $\begin{array}{c}\text { Pengetahuan } \\
\text { Naik }\end{array}$ & 15 & 83,30 \\
\hline \multicolumn{4}{|c|}{ Total } \\
\hline
\end{tabular}

Berdasarkan Tabel 3 diatas dapat diinformasikan bahwa hasil evaluasi penilaian tingkat pengetahuan para peserta sosialisasi menurut perbaidngan hasil penilaian pretest dan posttest, diketahui bahwa mayoritas para peserta mengalami peningkatan pengetahuan mengenai perencanaan program atas pemanfaatan dana desa $(83,30 \%)$. Sedangkan para peserta yang memiliki hasil akhir posttest sama dengan pretest adalah sebanyak 3 orang $(16,70 \%)$. Arti tetap dalam hal ini adalah terdapat 3 peserta yang mendapatkan nilai sama baik sebelum maupun setelah selesai sosialisasi. Hal ini menandakan telah terjadi peningkatan pengetahuan dari para peserta yang menjadi lebih baik setelah pelaksanaan sosialisasi. Poin penting penilaian sebagai bentuk evaluasi penilaian pengetahuan terdiri dari 3 aspek, yaitu peran perencanaan terhadap anggaran, proses dan sumber data untuk perencanaan, dan pelaksanaan perencanaan serta evaluasi. Tingkat pengetahuan terendah peserta terletak pada aspek proses pelaksanaan perencanaan dan sumber data yang digunakan dalam perencanaan. Hal tersebut mengindikasikan bahwa sampai saat ini, para peserta belum menggunakan data sebagai dasar perencanaan. Setelah pelaksanaan posttest, tingkat pengetahuan para peserta terkait proses dan sumber data perencanaan mengalami peningkatan. Secara keseluruhan, tingkat pengetahuan para peserta pada 3 aspek yang diukur menunjukkan peningkatan yang lebih baik. Pengetahuan seseorang dapat terus berubah dan berkembang sesuai dengan kemampuan, kebutuhan dan pengalaman serta tinggi rendahnya mobilitas dalam mendapatkan materi informasi tentang lingkungannya. Akses dalam mendapatkan informasi juga memiliki peran yang penting untuk meningkatkan pengetahuan (Situmorang, 1995). Menurut Fadlil (2011), faktor yang mempengaruhi tingkat pengetahuan seseorang dapat berasal dari faktor internal dan faktor eksternal. Selama penelitian didapatkan informasi bahwa rata-rata perangkat desa memiliki wawasan pengetahuan yang lebih baik daripada para kader desa. Hal ini terlihat dari nilai postest yang diperoleh para perangkat desa. Umumnya para kader desa memiliki progress yang lebih baik terkait perubahan tingkat pengetahuan dari evaluasi kedua penilaian (pretest dan post-test).

\section{Hasil Uji Pre-test dan Post-test secara Statistik}

Berikut merupakan detail informasi keterkaitan karakteristik dari para peserta dengan pengetahuan perencanaan berbasis bukti.

Tabel 4. Hubungan Posisi atau Jabatan dengan Penilaian Pre-test

\begin{tabular}{|c|c|c|c|c|}
\hline \multirow[t]{2}{*}{ No } & \multirow[t]{2}{*}{ Posisi } & \multicolumn{2}{|c|}{ Penilaian Pre-test } & \multirow[t]{2}{*}{ Total } \\
\hline & & Cukup & Baik & \\
\hline 1. & $\begin{array}{l}\text { Perangkat } \\
\text { Desa } \\
\text { Jumlah } \\
\text { Persentase }\end{array}$ & $\begin{array}{c}7 \\
53,90 \%\end{array}$ & $\begin{array}{c}6 \\
46,20 \% \\
\end{array}$ & $\begin{array}{c}13 \\
100,00 \%\end{array}$ \\
\hline 2. & $\begin{array}{l}\text { Kader } \\
\text { Jumlah } \\
\text { Persentase }\end{array}$ & $\begin{array}{c}4 \\
80,00 \%\end{array}$ & $\begin{array}{c}1 \\
20,00 \%\end{array}$ & $\begin{array}{c}5 \\
100,00 \%\end{array}$ \\
\hline
\end{tabular}




\begin{tabular}{|c|c|c|c|c|}
\hline \multirow[t]{2}{*}{ No } & \multirow[t]{2}{*}{ Posisi } & \multicolumn{2}{|c|}{ Penilaian Pre-test } & \multirow[t]{2}{*}{ Total } \\
\hline & & Cukup & Baik & \\
\hline \multicolumn{2}{|c|}{$\begin{array}{l}\text { Total } \\
\text { Jumlah } \\
\text { Persentase }\end{array}$} & $\begin{array}{c}11 \\
61.20 \%\end{array}$ & $\begin{array}{c}7 \\
38.90 \%\end{array}$ & $\begin{array}{c}18 \\
100,00 \%\end{array}$ \\
\hline
\end{tabular}

Berdasarkan Tabel 4 dapat diperoleh informasi bahwa rata-rata perangkat desa memiliki wawasan pengetahuan yang lebih baik daripada para kader desa. Hal ini terlihat dari nilai pre-test yang diperoleh para perangkat desa lebih baik.

Tabel 5. Hubungan Posisi atau Jabatan dengan Penilaian Post-test

\begin{tabular}{|c|c|c|c|c|}
\hline \multirow[t]{2}{*}{ No } & \multirow[t]{2}{*}{ Posisi } & \multicolumn{2}{|c|}{ Penilaian Posttest } & \multirow[t]{2}{*}{ Total } \\
\hline & & Cukup & Baik & \\
\hline 1. & $\begin{array}{l}\text { Perangkat Desa } \\
\text { Jumlah } \\
\text { Persentase }\end{array}$ & $\begin{array}{c}1 \\
7,70 \%\end{array}$ & $\begin{array}{c}12 \\
92,30 \%\end{array}$ & $\begin{array}{c}13 \\
100,0 \\
0 \%\end{array}$ \\
\hline 2. & $\begin{array}{l}\text { Kader } \\
\text { Jumlah } \\
\text { Persentase }\end{array}$ & $\begin{array}{c}0 \\
0,00 \%\end{array}$ & $\begin{array}{c}5 \\
100,00 \%\end{array}$ & $\begin{array}{c}5 \\
100,0 \\
0 \%\end{array}$ \\
\hline & $\begin{array}{l}\text { Total } \\
\text { Jumlah } \\
\text { Persentase }\end{array}$ & $\begin{array}{c}1 \\
5,60 \%\end{array}$ & $\begin{array}{c}17 \\
94,40 \%\end{array}$ & $\begin{array}{c}18 \\
100,0 \\
0 \%\end{array}$ \\
\hline
\end{tabular}

Tabel 6 Hubungan Posisi atau Jabatan dengan

Perubahan Tingkat Pengetahuan

\begin{tabular}{|c|c|c|c|c|c|c|c|}
\hline \multirow{2}{*}{ No. } & Posisi & \multicolumn{4}{|c|}{$\begin{array}{l}\text { Perubahan Tingkat } \\
\text { Pengetahuan }\end{array}$} & \multicolumn{2}{c|}{ Total } \\
\cline { 3 - 8 } & & $\begin{array}{l}\text { Pengetahuan } \\
\text { Tetap }\end{array}$ & \multicolumn{2}{c|}{$\begin{array}{l}\text { Pengetahuan } \\
\text { Naik }\end{array}$} & \multicolumn{2}{|c|}{} \\
\cline { 2 - 8 } & $\mathrm{n}$ & $\%$ & $\mathrm{n}$ & \multicolumn{1}{c|}{$\mathrm{n}$} & $\%$ \\
\hline 1. & $\begin{array}{l}\text { Perangkat } \\
\text { Desa }\end{array}$ & 3 & 23,10 & 10 & 76,90 & 13 & 100 \\
\hline 2. & Kader & 0 & 0,00 & 5 & 100,00 & 5 & 100 \\
\hline \multicolumn{2}{|r|}{ Total } & 3 & 16,70 & 15 & 83,30 & 18 & 100 \\
\hline
\end{tabular}

Berdasarkan Tabel 5 dapat diperoleh informasi bahwa rata-rata perangkat desa memiliki wawasan pengetahuan yang lebih baik daripada para kader desa. Hal ini terlihat dari nilai posttest yang diperoleh para perangkat desa lebih baik. Berdasarkan Tabel 6 dapat diperoleh informasi bahwa umumnya para kader desa memiliki progress yang lebih baik terkait perubahan tingkat pengetahuan dari penilaian pretest dilanjutkan posttest. Sosialisasi ini sebagai wujud bakti perguruan tinggi dalam mengabdi dan membagikan wawasan, pengetahuan dan pengalaman agar dapat meningkatkan pemahaman masyarakat sekitar. Efektivitas dalam pemberian sosialisasi terhadap peningkatan pengetahuan peserta tentang perencanaan berbasis bukti, diukur melalui mekanisme evaluasi pretest dan posttest serta membandingkan hasil evaluasi penilaian pretest dan posttest. Sebelum dilakukan pengujian efektivitas pemberian sosialisasi dalam perubahan peningkatan pengetahuan, maka perlu dilakukan pengujian normalitas data sebagai syarat pengujian analisis statistik parametrik dengan data berskala interval/rasio. Hasil dari pengukuran tersebut sebagai berikut.

Tabel 7. Distribusi Normalitas Data

\begin{tabular}{|c|l|l|l|l|}
\hline No. & Uraian & Signifikansi & Syarat & Keterangan \\
\hline 1. & $\begin{array}{l}\text { Evaluasi } \\
\text { pre-test }\end{array}$ & 0,170 & $>$ & Normal \\
\cline { 1 - 2 } 2. & $\begin{array}{l}\text { Evaluasi } \\
\text { post-test }\end{array}$ & 0,001 & & $\begin{array}{l}\text { Tidak } \\
\text { Normal }\end{array}$ \\
\hline
\end{tabular}

Berdasarkan Tabel 7 dapat diperoleh informasi bahwa data evaluasi pretest dan posttest tidak memenuhi syarat distribusi normal. Oleh sebab itu, uji statistik selanjutnya diperkenankan menggunakan uji statistik dengan kelompok non parametrik. Uji yang disarankan adalah dengan uji Wilcoxon. Uji ini digunakan untuk melihat ada perubahan peningkatan pengetahuan atau tidak setelah diberikan sosialisasi, dalam hal ini mengamati perubahan yang terjadi antara evaluasi pre-test dan post-test. Hasil uji statistik menggunakan Wilcoxon menunjukkan nilai signifikansi yang diperoleh sebesar 0,001 (lebih kecil dari nilai alfa $(\alpha)=0,05)$. Oleh sebab itu, kesimpulan yang dapat diambil adalah terdapat perbedaan yang signifikan antara evaluasi pre-test dan post-test. Rata-rata penilaian evaluasi posttest adalah 93,06 dan lebih baik daripada rata-rata penilaian evaluasi pretest yaitu 77,78. Hal ini menandakan adanya efektivitas pemberian sosialisasi dalam meningkatkan pengetahuan para peserta.

\section{KESIMPULAN}

Penelitian ini diikuti oleh 18 responden terdiri atas perangkat desa dan kader. Pengukuran pengetahuan menggunakan pretest dan post-test. Hasil pre-test terbanyak adalah dalam kategori pengetahuan cukup baik $(61,11 \%)$ dan post-test dalam kategori pengetahuan baik $(94,44 \%)$. Penilaian meningkat pada post-test sebanyak 15 peserta $83,33 \%$. Pengukuran pengetahuan para peserta mengenai pemanfaatan dana desa meliputi peran perencanaan terhadap anggaran, proses dan sumber data untuk perencanaan, pelaksanaan perencanaan dan evaluasi. Penilaian pengetahuan terendah dari para peserta terletak pada aspek proses pelaksanaan perencanaan dan sumber data yang dapat digunakan dalam perencanaan. Hasil 
penilaian post-test dapat diketahui bahwa tingkat pengetahuan peserta mengenai proses dan sumber data perencanaan meningkat hingga 92,2\%. Secara keseluruhan, tingkat pengetahuan para peserta pada 3 aspek yang diukur, menunjukkan adanya peningkatan yang lebih baik.

Berdasarkan posisi jabatan dengan skor pretest dan post-test, perangkat desa memiliki tingkat pengetahuan lebih baik daripada kader desa. Namun, peningkatan pengetahuan yang lebih baik dimiliki oleh kader desa dibandingkan dengan perangkat desa. Efektivitas sosialisasi secara statistik dihitung melalui uji Wilcoxon menunjukkan nilai signifikansi, 0,001 (kurang dari nilai $\alpha)=0,05$. Hasil tersebut menunjukkan terdapat perbedaan yang signifikan antara evaluasi pre-test dan post-test. Hal ini menandakan adanya efektivitas pemberian sosialisasi dalam meningkatkan pengetahuan para peserta.

\section{DAFTAR PUSTAKA}

Trihono, Swandono A, Sudomo. 2014. Badan Penelitian dan Pengembangan Kesehatan Indonesia. Indeks Pembangunan Kesehatan Masyarakat (IPKM) 2013. Kedua, editors. Jakarta: Lembaga Penerbit Balitbangkes (LPS)

Badan Perencanaan dan Pengembangan Nasional. 2015. Pembangunan Desa dan Kawasan Perdesaan dalam RPJMN 2015-2019.

Firdausi, N.J \& Adriansyah, A.A. 2017. Pengenalan Perencanaan Program Desa Berbasis Bukti Di Desa Murtajih, Kecamatan Pademawu, Kabupaten Pamekasan. Surabaya: Unusa Press

Firdausi, N.J., Adriansyah, A.A \& Rhomadhoni, M.N. 2017. Analisis Dampak Dana Desa Terhadap Pembangunan Kesehatan Masyarakat Di Desa Murtajih Kabupaten Pamekasan. Surabaya: Unusa Press.

Hamidi, H., Setijonegoro F.N., Fujitriartanto, Sa'id A, Harioso \& Huda. 2015. Indeks Desa Membangun 2015 [Internet]. Kementrian Desa. Pembangunan Daerah Tertinggal dan Transmigrasi. Jakarta: Kementrian Desa. Pembangunan Daerah Tertinggal dan
Transmigrasi; 293 p. Available from: http://kedesa.id/wpcontent/uploads/2016/05/INDEKS-DESAMEMBANGUN-final.pdf

Jurniadi, Djumadi \& Paranoan, D. 2015. FaktorFaktor yang Berpengaruh terhadap Efektivitas Penyaluran Alokasi Dana Desa di Kecamatan Teluk Pandan Kabupaten Kutai Timur. Journal Administrative Reform. Vol 1(1). 112-124 pp. Available from: http://ejournals1.undip.ac.id/index.php/accounting

Kementerian Kesehatan RI. 2015. Rencana Strategis Kementrian Kesehatan Tahun 20152019. [Internet]. Jakarta: Kementrian Kesehatan RI;. Available from: http://www.depkes.go.id/resources/download/ info-publik/Renstra-2015.pdf

Kementerian Kesehatan RI. 2012. Ayo ke Posyandu Setiap Bulan. [Internet]. Buku Saku. Jakarta: Pusat Promosi Kesehatan Kementrian Kesehatan RI. 1-32 p. Available from: www.promkes.depkes.go.id

Kementerian Kesehatan RI. 2010. Kepmenkes Nomor 1529/Menkes/SK/X/2010 Tentang Pedoman Umum Pengembangan Desa dan Kelurahan Siaga Aktif. Jakarta: Kementrian Kesehatan RI;. 351.077.Ind p.

Kementerian Keuangan Republik Indonesia. 2017. Tentang Kebijakan Dana Desa Tahun 2017.

Letty, N.L.A. 2016. Otonomi Desa dan Efektivitas Dana Desa. Jurnal Penelitian Politik. Vol 13(2). 193-211 pp.

Permendes Nomor 22 Tahun 2016 Tentang Penetapan Prioritas Penggunaan Dana Desa Tahun 2017.

Restuastuti, T., Chandra, F \& Restila, R. 2017. Analisis Pemberdayaan Masyarakat di Bidang Kesehatan. Jurnal Kesehatan Melayu. Vol 1(1). 14-9 pp.

Sutisna, E., Ravik, S., Bhisma, K., Drajat, M., Kartono, T \& Rifai, W. 2006. Model Pemberdayaan Masyarakat Bidang Kesehatan, Studi Program Desa Siaga. Jurnal 
Kesehatan Masyarakan Nasional. Vol 7(36).186-92 pp.

Sutiyono, G., Rakhmadi, R., Muluk, S \& Mafira T. 2018. Indonesia's Village Fund: An Important Lever for Better Land Use and Economic Growth at the Local Level : A
Climate Policy Initiative [Internet]. Vol. 1, Report.. Available from: https://climatepolicyinitiative.org/wpcontent/uploads/2018/04/Indonesia's-VillageFund-_-An-Important-Lever-for-Better-LandUse-and-Economic-Growth-at-the-LocalLevel.pdf 